\title{
Why Are Some Spanish Regions So Much More Efficient Than Others?
}

\author{
JAUME PUIG-JUNOY* and JAIME PINILLA† \\ * Department of Economics and Business, Pompeu Fabra University, C/ Trias Fargas \\ 25-27, 34-08005 Barcelona, Spain. E-mail: jaume.puig@upf.edu \\ † Department of Quantitative Methods, University of Las Palmas, Campus de Tafira, \\ 34-35017 Las Palmas de Gran Canaria, Spain. E-mail: jpinilla@dmc.ulpgc.es
}

\begin{abstract}
This article investigates the main sources of heterogeneity in regional efficiency. We estimate a translog stochastic frontier production function in the analysis of Spanish regions in the period 1964-1996, to attempt to measure and explain changes in technical efficiency. Our results confirm that regional inefficiency is significantly and positively correlated with the ratio of public capital to private capital. The proportion of service industries in the private capital, the proportion of public capital devoted to transport infrastructures, the industrial specialization, and spatial spillovers from transport infrastructures in neighbouring regions significantly contributed to improve regional efficiency.
\end{abstract}

Key Words: Regional efficiency, Regional spillovers, Human capital, Public capital.

JEL classifications: C23, H54, R11, R53. 


\section{Why Are Some Spanish Regions So Much More Efficient Than Others?}

\section{NTRODUCTI ON}

Output per worker not only varies enormously among countries (Hall and Jones, 1999), but also presents a large amount of variation at regional level in developed countries. This is the case, for example, in Spain, where output per worker in the most productive region was $57 \%$ higher than in the least productive one in 1996. Explaining the level and trends of such differences in economic performance may be one important contribution of applied economics to the design of public and private policies in order to improve welfare and reduce inequalities.

Regional economic growth can be decomposed into two main components: increases in factor inputs (capital accumulation), and improvements in total factor productivity. The first component attributes differences among regions to differences in physical resources, physical capital, and labour. Notwithstanding, public and private policies attempting to reduce differences in factor inputs will not be sufficient to guarantee a proportional reduction in economic performance differences among regions. The main reason is that productivity differences, the second component, may also play a determinant role in economic growth.

Increases in total factor productivity may be achieved through technical change (shifts in the production frontier) and through reductions in inefficiency in the production (movements toward the frontier). In the long run, it can be hypothesized that technology transfers allow relatively homogeneous or similar regions, such as those in a developed country, to grow at a common rate. Then, not all differences in total factor productivity need be persistent. That is, we may expect regional technology gaps among regions in developed countries to close over time as technology diffuses. If this is the case, persistent differences in total factor productivity may be attributed mainly to inefficiency in the use of input factors to produce regional output. 
Given the relatively small variation in inputs per worker among the regions of a developed country, and homogeneous technology diffusion, it is not difficult to conclude that differences in efficiency, despite the political emphasis on the explanatory power of differences in factor inputs, as continues to be the case in Spain, may play a key role in generating variation in output per worker among regions in developed countries.

The traditional regional production function approach omits the influence of the level and evolution of technical inefficiency on the production function, and it precludes measurement of technical inefficiencies by assuming them away. Measuring regional inefficiency in production makes it possible to distinguish between shifts in technology and movements towards the best-practice production frontier. By estimating the bestpractice production function (an unobservable function) this approach calculates regional technical efficiency as the distance between the best production practice (the frontier) and the observed output. In this context, given regional input factors, differences in economic performance could be greatly reduced by improving technical efficiency. A frontier approach to inefficiency measurement makes it possible to separate efficiency change from technical change, rather than simply calculating the contribution of productivity as a residual, as is usually done in the growth accounting literature (Murillo-Zamorano, 2004).

This paper puts the emphasis on explaining cross-regional differences in output inefficiency levels and how and why efficiency varies among regions, with a specific application to Spanish regions. There has been an abundant empirical literature reporting major variations in aggregate frontier production functions since the initial paper by Färe, Grosskopf, Norris and Zhang (1994). There are also a number of papers reporting inefficiency heterogeneity for decentralized regions or states in developed countries such as the United States (Domazliky and Weber, 1997), or Italy (Percoco, 2004) and Spain (Maudos, Pastor and Serrano, 1997) in the European Union.

Despite the critical importance for regional growth of reducing the distance from the best practice, the empirical literature has paid little attention to the sources of regional differences in technical efficiency, as a disaggregated component of total factor productivity, in decentralized and developed countries. Boisso, Grosskopf and Hayes (2000) used a non-parametric frontier approach and a two-step approach to explore factors that may lead to changes in the efficiency index calculated for U.S. states using 
a panel of 48 states over the period 1970-1986. These authors considered the influence of the business cycles, the magnitude of the service sector relative to manufacturing, the ratio of private capital to labour, the ratio of highway capital stock to private capital stock, the importance of the private sectors relative to their total economy, and the "network" effect on the efficiency change index. Their results indicate that neighbours' capital has an insignificant negative effect on efficiency change. Puig-Junoy (2001) investigated the effects of public capital level and composition on the efficiency of 48 contiguous U.S. states in the period 1970-1983 using a parametric frontier approach. The results of this study suggest that a higher ratio of public to private capital is related to higher inefficiency scores, and that the composition of public capital also affects inefficiency: the proportion of public capital devoted to highways is negatively correlated with technical inefficiency.

Spanish evidence on heterogeneity in regional technical efficiency has been reported in several published papers. A non-systematic review of the evidence reported by recent research into the frontier estimation of parametric and non-parametric inefficiency scores in studies considering whole regional economies in Spain as the observation unit (Maudos, Pastor and Serrano, 1998; Gumbau-Albert, 1998; Maundos, Pastor and Serrano, 2000; Gumbau-Albert, 2000; Pedraja, Salinas and Salinas, 2002; Salinas, 2003; Bosch, Espasa and Sorribas, 2003; Rodríguez-Vález and Arias-Sampedro, 2004) clearly shows that: (i) there is considerable variation in regional inefficiency scores among Spanish regions, which indicates ample potential for growth by reducing the distance from the best practice; and (ii) regional inefficiency is the main driving force explaining productivity and output per worker changes among Spanish regions.

Research on sources of variation in Spanish regional inefficiency is scarce and less conclusive. Using a non-parametric method (Data Envelopment Analysis, DEA) and a two-step approach, Maudos, Pastor and Serrano (1998) investigate the influence of public and human capital and agriculture output share on inefficiency scores for Spanish regions in the period 1964-1991. Using a stochastic frontier function, Bosch, Espasa and Sorribas (2003) find a positive influence of European Union transfers to Spanish regions and of the public to private capital ratio on efficiency scores for the period 1986-1996. Rodríguez-Vález and Arias-Sampedro (2004), also using a stochastic frontier for the period 1980-1998, conclude precisely the opposite, that is, a higher ratio of public to private capital significantly increases inefficiency. 
The principal aim of this paper is to estimate a translog stochastic frontier production function in the analysis of the 17 Spanish regions (17 Autonomous Communities, excluding the two African autonomous cities, which correspond to the Nomenclature of Territorial Units for Statistics NUTS2) in the period 1964-1996 in order to measure and explain changes in regional technical efficiency. The model uses real gross value added (GVA) as the output, and total employment, private capital and public capital as inputs. The model allows technical inefficiency to vary over time, and inefficiency effects to be a function of a set of explanatory variables in which the industrial specialization, spatial spillovers, and the level and composition of public and private capital play an important role.

The paper contributes to the existing literature on regional productivity and efficiency in the following ways. First, it estimates a stochastic production frontier function for all Spain's regional economies, explicitly introducing public capital and human capital adjusted-labour as inputs, which allows the estimation of regional technical inefficiencies and their confidence intervals. Second, it estimates the marginal impact of regional variations in the level and composition of public and private capital on technical inefficiency. Third, we consider Hulten and Schwab's (1991) "network" effect by measuring the impact of neighbouring regions' public capital devoted to transport infrastructures on "home" region efficiency.

The paper continues with the following structure. The second section outlines the stochastic frontier approach with the inefficiency effects models and presents a brief description of the data. The third section presents the empirical results derived from these models. The final section deals with the main conclusions and practical implications of this research.

\section{METHOD AND DATA}

Our method constructs a best-practice frontier from the data in the sample (i.e., we construct a national frontier and compare individual regions with that frontier). Frontier approaches do not necessarily observe the true (unobserved) technological frontier, only the best-practice reference technology. An observation is technically inefficient if it does not minimize its input given its output. Efficiency scores of unity imply that the 
region (the unit of observation) is on the national frontier in the associated year. Efficiency scores lower than unity imply that the region is below the frontier: in this case, a further proportional increase in output is feasible, given productive factor quantities and technology. We assume that each region attempts to maximize output from a given set of inputs. Note that regional or country studies consider the sum of all micro-units as a single production unit and assume away differences between firms within each national industry. Aggregate estimates of frontier production functions, in the tradition of Färe, Grosskopf, Norris and Zhang (1994), also assume that in the medium and long term, regions may introduce changes in their productive specialization in those sectors that are more or less productive in order to improve efficiency. Then, aggregate efficiency changes will measure changes associated to the composition of production (composition efficiency) and intra-sector efficiency changes (Maudos, Pastor, and Serrano, 2000). However, as it is considered in this paper, sector composition has to be accounted for as a source of potential regional inefficiency variation.

The panel data set used in this research is taken from SOPHINET, a database produced by the Fundación BBVA and IVIE. The BBVA-IVIE database is the main source of information for this study given that many variables are not provided by official Spanish economic statistics (private and public capital, and level of education), even though they are usually provided by official economic statistics in other countries. Capital stock series in this database have been generated using internationally accepted methods that allow comparison with other databases.

Our database has been completed using data for gross value added (GVA) from the BBV database and BD.MORES (Dabán et al, 1998), produced by the University of Valencia and the Spanish Ministry of Economics and Finance (http://www.sgpg.pap.meh.es). The link between both sources for this variable has been performed using the approach proposed by Doménech, Escribà and Murgui (1999). This approach uses disaggregated information for four sectors (agriculture, industry, construction, and services) considering time trends of the prices and the mix in each sector.

The BD.MORES and SOPHINET databases are two of the most utilized databases to study the Spanish economy. We combined the information in BD.MORES and SOPHINET in order to differentiate between private and public capital, and to obtain 
longer time series, despite not having been still able to incorporate adequate information for the most recent years. Compatibility and methodological differences between these databases have been described in Boscá, Escribá and Murgui (2003).

The balanced panel data set covers the 17 Spanish regions for the period 1964 to 1996. The data consist of 33 annual observations. The gross regional (private and public) value added $Y$ is used as a measure of output. Human capital-adjusted labour supply HL, total private capital K, and total public capital G represent the inputs in the production function. Monetary values are evaluated at 1986 prices. Detailed sources and a more accurate description of data construction may be found at http://www.ivie.es.

Unadjusted total employment $L$ (workers between the ages of 15 and 64 years) has been adjusted for human capital accumulation. Results from previous empirical studies of economic growth across countries have revealed that production function parameters can change significantly when measures of labour adjusted for human capital are included as inputs. Following Tallman and Wang (1994) and Duffy and Papageorgiou (2000), we define HL as a proxy measure for human capital adjusted labour input. A similar approach has also been employed recently in the production frontier approach literature (Maudos et al, 2003; Kumbhakar and Wang, 2005). Human capital $(\mathrm{H})$ is defined as the mean years of schooling of the labour force. The mean school years of education is defined as the sum of the average number of years of primary, secondary, and postsecondary education. $\mathrm{HL}$ is calculated as the product of $\mathrm{L}$ and $\mathrm{H}$ in each region and year. The source of these data is the IVIE database available at http://www.ivie.es.

Table 1 presents the summary statistics for the variables included in the analysis. They involve the mean value and the standard deviation, together with the minimum and maximum values.

\section{[ Insert Table 1 about here ]}

We consider a panel data model for inefficiency effects in stochastic production frontiers based on the Battese and Coelli (1995) model. Our stochastic production frontier model allows: (i) technical inefficiency and input elasticities to vary over time in order to detect changes in the production structure; and (ii) inefficiency effects to be 
a function of a set of explanatory variables the parameters of which are estimated simultaneously with the stochastic frontier. Time-invariant efficiency would be an unrealistic assumption given that elimination of slack compresses the efficiency distribution, whereas generation of slack works the opposite way (Kumbhakar, Heshmati and Hjalmarsson, 1997). The approach is stochastic and regions may be off the frontier because they are inefficient or because of random shocks or measurement errors. Efficiency is measured by separating the efficiency component from the overall error term.

The stochastic frontier production function model with panel data is written as:

$$
\begin{array}{r}
\mathbf{Y}_{\text {it }}=\mathrm{f}\left(\mathbf{X}_{\text {it; }} ;\right) \mathrm{e}^{(\text {Vit }-\mathbf{U i t})} \quad \mathrm{i}=1,2, \ldots, 17 \\
\mathrm{t}=1,2, \ldots, 33
\end{array}
$$

where

$\mathbf{Y}_{\mathrm{it}}$, is the gross regional value added at the th observation for the ith regions;

$f(\bullet)$ represents the production technology;

$\mathbf{X}_{\mathrm{it}}$ is a vector of input quantities of the ith region in the th time period;

$\beta$ is a vector of unknown parameters;

$\mathbf{V}_{\text {it }}$ are random variables which are assumed to be iid. $\mathrm{N}\left(0, \sigma_{\mathrm{v}}{ }^{2}\right)$;

$\mathbf{U}_{\text {it }}$ are non-negative unobservable random variables associated with the technical inefficiency in production, such that the observed output falls short of its potential output for the given technology and level of input.

In the technical inefficiency effects model the error term is composed of the following two components: technical inefficiency effect and statistical noise. A region-specific effect is not explicitly considered in the estimated production function model because it would be considered as persistent technical inefficiency, which implies that we do not consider the existence of unobserved systematic effects that vary among regions in the production function (Heshmati, Kumbhakar and Hjalmarsson, 1995).

The technical inefficiency effect $U_{\text {it }}$ may be specified as

$$
\mathbf{U}_{\text {it }}=\mathbf{z}_{\text {it }} \delta+\mathbf{W}_{\text {it }}
$$

where 
$\mathbf{U}_{\text {it }}$ are non-negative random variables that are assumed to be independently distributed as truncation at zero of the $\mathrm{N}\left(\mathbf{m}_{\mathrm{it}}, \sigma_{\mathrm{u}}{ }^{2}\right)$ distribution;

$\mathbf{m}_{\text {it }}$ is a vector of region-specific effects, with $\mathbf{m}_{\text {it }}=\mathbf{z}_{\text {it }} \delta$;

$\mathbf{z}_{\text {it }}$ is a vector of variables which may influence the efficiency of the region;

$\delta$ is a vector of parameters to be estimated;

$\mathbf{W}_{\text {it, }}$ the random variable, is defined by the truncation of the normal distribution with mean zero and variance $\sigma^{2}$, such that the point of truncation is $-\mathbf{z}_{\text {it }} \delta$.

Two-step procedures to estimate the determinants of the technical inefficiency, formerly used in the parametric literature, suffer from a fundamental contradiction. The second stage involves the specification of a regression model for the predicted technical inefficiency effects that contradicts the identical distribution assumption of the first stage. The Battese and Coelli (1995) model overcomes this contradiction and allows the simultaneous estimation of the parameters of the stochastic frontier and the inefficiency model.

Given the aim of our study, the investigated sources of regional differences in technical efficiency are limited to the influence of the level and composition of public and private capital, spatial spillovers, and industrial mix as a potential determinant of differences among regions. Six explanatory variables associated with technical inefficiency are defined according to our hypothesis about the sources of inefficiency: (1) the ratio of public capital to private capital G/K, (2) the proportion of public capital invested in transport infrastructures TI/G (ports, airports, railways, motorways and roads), (3) the proportion of service industry capital in the private capital S/K, (4) spatial productivity spillovers SS, (5) the industrial mix index (IMI), and (6) the time trend t.

The ratio of public capital to private capital $(G / K)$, and the proportion of public capital invested in transport infrastructures $(\mathrm{TI} / \mathrm{G})$ have also been used as factors explaining inefficiency variation in a similar paper (Puig-Junoy, 2001).

In the last decades, a structural change has been observed in the Spanish economy relating to the mix of the capital stock for the main productive sectors: the service sector has the highest rate of growth, and correspondingly, agriculture and also industry, likewise in recent years, have lost relative importance (Mas et al, 2006). In this paper, we use the proportion of service industry capital in the private capital (S/K) 
in order to verify its influence on the magnitude of and changes in regional inefficiency levels.

Lower productivity of public capital when researchers estimate regional production functions using state-level data than when using aggregate national time-series data has been attributed to the existence of spillovers of public capital from one region to the neighbouring regions (Holtz-Eakin and Schwartz, 1995; Alvarez et al, 2006). Spatial spillovers may appear because many elements of public capital have network characteristics (e.g., roads, highways, railways, etc.). In this paper, following recent economic literature, spillover effects from public capital in neighbouring regions have also been considered in the inefficiency effects models. We are interested in the degree to which regional efficiency is also influenced by public capital in neighbouring regions (efficiency spillovers from road infrastructures). Spatial productivity spillovers SS have been measured in this paper as neighbouring regions' public capital in motorways and roads by area (in square metres).

Regional specialization may also be hypothesized to play an important role in explaining higher or lower inefficiency levels. The approach adopted in this paper is to obtain a proxy measure of regional specialization and to compare each regional's industrial structure with that of the average of the rest of the regions of the country. The industrial-mix index employed in this paper is the Krugman specialization index ${ }^{1}$ which is usually employed in empirical research as a proxy of industrial mix specialization (Maza and Villaverde, 2007). This indicator takes value zero if region $\mathrm{i}$ has an industrial structure identical to the rest of the country, and takes maximum value of two if it has no industries in common with the rest of the industry.

To limit the restrictive properties imposed on the production process, the translog production function is chosen and tested against the restricted Cobb-Douglas functional form. The translog functional form is widely accepted as it is conceptually simple and imposes no a priori restrictions on the structure of technology. A translog production function which also takes account of non-neutral technical change is given by: 


$$
\begin{aligned}
\ln Y_{i t}= & \beta_{0}+\sum_{k=1}^{K} \beta_{k} \ln X_{k i t}+\sum_{j=1}^{K} \sum_{k=1}^{K} \beta_{j k} \ln X_{j i t} \ln X_{k i t}+ \\
& \sum_{k=1}^{K} \beta_{t k} \ln X_{k i t} t_{k}+\beta_{t 1} t+\beta_{t 2} t^{2}+\varepsilon_{i t}
\end{aligned}
$$

where $\mathbf{Y}$ is the log of gross regional value added and $\mathbf{X}$ is a vector of the logarithms of the three inputs considered $(j, k=L, K, G)$ where the technological change can be specified as an additional input (time trend $\mathrm{t}$ ) representing the rate of technical change or the shift in the production function over time. This specification makes it possible to consider time-varying efficiencies and non-neutral technical change.

The output-based Farrel measures of technical efficiency of each region i in year $t$ may be estimated as: $\mathrm{TE}_{\mathrm{it}}=\exp \left(-\mathrm{U}_{\mathrm{it}}\right)$.

\section{EMPI RI CAL RESULTS}

Following Battese and Coelli (1995), maximum likelihood estimation (performed using FRONTIER 4.1; Coelli, 1996) was employed to simultaneously estimate the parameters of the stochastic production frontier and the technical inefficiency effects model. The results of this procedure are presented in Table 2 . The variance parameters are expressed in terms of $\gamma=\sigma_{u}{ }^{2} /\left(\sigma_{u}{ }^{2}+\sigma_{v}{ }^{2}\right)$. The estimates of the first-order coefficients of the variables in the translog function cannot be directly interpreted as elasticities.

\section{[ Insert Table 2 about here ]}

A number of statistical tests were carried out to identify the appropriate functional forms and the presence of inefficiency and its trend. As a misspecification analysis we used log-likelihood ratio (LR) tests. LR tests were performed to test various null hypotheses as listed in Table 3. Given the specification of the technical inefficiency effects model, the first test shows that the null hypothesis that the Cobb-Douglas functional form is preferred to the translog is rejected. The null hypothesis is rejected by the test at the $5 \%$ level and hence all results presented here refer solely to the translog. Also, in test 2, the null hypothesis that there is no technological change in 
the Spanish regions' production is rejected. Hence technical change is present in the model.

\section{[ Insert Table 3 about here ]}

The null hypothesis explored in test 3 is that each region is operating on the technically efficient frontier and that the systematic and random technical inefficiency effects are zero. The null hypothesis that $\gamma$ is zero is rejected, suggesting that inefficiency was present in production and that the average production function is not an appropriate representation of the data. Tests 4 and 5 consider the null hypothesis that the inefficiency effects are not a function of the explanatory variables. Again, the null hypothesis is rejected, confirming that the joint effect of these variables on technical inefficiency is statistically significant.

A high degree of multicollinearity was observed in the translog stochastic frontier using the condition index. When the objective is to estimate output elasticities, the parameter estimates of the translog form are too unreliable because of the use of a flexible functional form and the attendant multicollinearity. Multicollinearity may affect the standard errors and the sign of the estimated coefficients in the production function. We checked that elasticities obtained from the model had the expected sign. Multicollinearity affects (increases) only the standard errors of the estimated coefficients and not their consistency. Notwithstanding, multicollinearity is not necessarily a serious problem given that the aim of this paper is to focus on efficiency estimation ${ }^{2}$.

Since the measurement of region-specific efficiency levels may be problematic due to high degrees of uncertainty, we adapt the approach of Horrace and Schmidt $(1996)^{3}$, to construct confidence intervals for stochastic frontier models to our panel with timevarying effects. Given the specification of the general translog stochastic frontier model, the average technical efficiency and 95\% confidence intervals for the 17 Spanish regions are presented in Table 4 and plotted in Figures 1 and 2.

[ Insert Table 4 about here ]

[ Insert Figures 1 and 2 about here ] 
In Table 4, we present the ranking of regions according to their efficiency levels for the average of the period 1964-1996. The unweighted mean technical efficiency of the 17 Spanish regions in the period $1964-1996$ is $93.6 \%$. That is, over the period analysed the average region produced $93.6 \%$ of maximum attainable output (i.e., its GVA could be increased by $6.6 \%$ without increasing the inputs). Mean efficiency values per year range from $80.9 \%$ in 1964 to $96.4 \%$ in 1996 . The minimum estimated efficiency is $87.3 \%$ and the maximum is $97.3 \%$. There is also a relatively small spread of inefficiencies, with only one region (Extremadura) showing mean efficiency values lower than $90 \%$. The mean efficiency score for Extremadura over the whole period indicates that its output could be increased by $14.5 \%$ without increasing the inputs. At the other extreme, throughout the whole period, the mean efficiency scores for País Vasco, Madrid, Baleares and Navarra indicate that they operated very close to the production frontier (Figures 1 and 2).

Given the differences in technical efficiency levels between regions and years it is appropriate to ask why some regions can achieve relatively high efficiency while other are technically less efficient. The parameter estimates presented in Table 2 suggest a number of public and capital related factors that may explain part of the variation in observed efficiency levels. We focused our attention on the role of the intensity and composition of public capital, the industrial specialization, spatial spillovers stemming from public transport infrastructures, private capital composition, and time trend effects as sources of variation in inefficiency levels. We tested the influence of public capital on the inefficiency levels of each region and year through the level of public capital in relation to private capital (G/K), the composition of public capital ( $\mathrm{Tl} / \mathrm{G})$, and spatial spillovers (SS). At the same time, private capital composition was tested using the proportion of primary and services sector capital to total private capital; however, only the proportion of capital in service industry to total private capital $(S / K)$ was retained in the preferred model. The influence of the industrial mix has been tested using the Krugman specialization index.

The parameter estimates for the inefficiency effects model presented in Table 2 are difficult to interpret. They only indicate the direction of the effects (sign effects, positive or negative) that these variables have upon inefficiency levels. However, quantification of the marginal effects of these variables on technical efficiency is possible by partial differentiation of the technical efficiency predictor with respect to each of the inefficiency effects variables. Table 5 presents the effect of a marginal 
change in the $k^{\text {th }}$ continuous variable $z_{k}$ on the technical efficiency ${ }^{4}$, which indicates both the direction and the strength of the influence a given variable has on efficiency. An estimated covariance matrix for all the marginal effects is computed using the delta method (Oehlert, 1992).

\section{[Insert Table 5 about here ]}

Table 5 shows that all of these effects are statistically significant at $95 \%$, indicating that they have an influence on relative efficiency levels. According to the coefficients several conclusions may be drawn. First, an increasing time trend in efficiency is observed during the period for the unweighted average of the 17 regions: each year, the average efficiency score experienced a rise of 3.0 percentage points (the estimates have a positive value of 0.0296). These results imply an average decline of inefficiency which slightly diminishes over time, as the coefficient of the square time trend indicates.

Second, those regions with higher levels of public capital in relation to private capital show lower levels of efficiency. Consequently, increases in the ratio of public to private capital will result in reduced technical efficiency levels: a public to private capital ratio 0.01 higher in one region than in another will result in an decrease of 0.44 percentage points in the efficiency score.

Third, as was observed in Puig-Junoy (2001) for the 48 U.S. states, the composition of public capital is also an important factor influencing inefficiency levels. In a decentralized country, regional decision makers not only decide about the amount of public investment; they also make decisions about the composition of such public investments. The marginal effect of the proportion of public capital devoted to transport infrastructures in relation to total public capital is positive, indicating that an increase in this proportion, maintaining the same level of public and private capital, will increase regional efficiency: a 0.01 point increase in this ratio will increase efficiency by $0.083 \%$.

Fourth, public investment in transport infrastructures in neighbouring regions also has a positive but less important influence on the efficiency level of the region which is not negligible: a 0.01 point increase in the SS measure will increase efficiency by $0.06 \%$. 
Fifth, sector composition of private capital in each region also has a major effect on the efficiency level: a region with an S/K ratio 0.01 points higher than another region will yield an efficiency score $1.28 \%$ higher than the latter.

And finally, our results indicate that a higher industrial specialization in comparison with other regions also has a positive contribution on regional efficiency: a region with an IMI 0.01 points higher than another region will yield an efficiency score $3.02 \%$ higher than the latter.

\section{CONCLUSI ONS}

Regions produce high levels of output in the long run because they achieve high rates of input factors and because they use these inputs with a higher level of efficiency in production. In this paper we investigated the main sources of heterogeneity in regional efficiency in developed countries with an application to the Spanish regions, given the potential for economic growth by reducing the distance from the best practice.

We estimated a translog stochastic frontier production function in the analysis of Spanish regions in the period 1964-1996, to attempt to measure and explain changes in technical efficiency. Our results indicate that since the early eighties the amount of relative regional inefficiency has been lower than in the sixties. Considering that inefficiency is the major source of regional disparities in TFP levels, then, the results presented in this paper indicate that TFP differences have reduced during the period and that they were more important in 1964 than in 1996. A similar intense process of convergence in efficiency levels among Spanish regions has also been observed by Salinas-Jiménez (2003) using a Data Envelopment Analysis for the period 1965-1995.

Notwithstanding, at the end of the period, an small average level of inefficiency persists (average relative efficiency level is 0.96 in 1996 in comparison to 0.81 in 1964), however some regional variations which still remain and deserve attention. These results indicate that in 1964 there was wider room for additional productivity improvements of less developed regions through inefficiency reduction in the sixties and seventies than it is in the nineties. 
The estimated levels of inefficiency for the Spanish regions between 1964 and 1996 estimated in this paper were on average around 6.4 percent. These average inefficiency levels are lower than those obtained by Salinas-Jiménez (2003), around 20\%) for a similar period (1965-1995) using a Data Envelopment Analysis approach, and those obtained by Gumbau-Albert (2000) using a stochastic frontier approach for the period 1964-1993. Our results indicate that inefficiency average levels for the Spanish regions are lower when introducing a human capital adjusted measure of labour and a public capital measure, instead of considering a rough measure of unadjusted labour and omitting the public capital as inputs in the productive function, as it has been the case in similar studies for Spanish regions.

We estimated an important contribution of the time trend to the overall reduction of inefficiency in all regions (around 3\% each year). This represents the decline in inefficiency which is identified by our model as common in all regions, and that can not be related with the regional behaviour of other inefficiency determinants. Further research should shed light on the sources of this common decline in inefficiency for all regions over time. At the end of the study period, efficiency gains can not be an important source of productivity growth, except for some regions (Andalucía, Extremadura, Galicia, Murcia).

Our results confirm that regional inefficiency is significantly and positively correlated with the ratio of public capital to private capital. A high proportion of service industries in the private capital, a high proportion of public capital devoted to transport infrastructures, a high industrial specialization, and spatial spillovers from transport infrastructures in neighbouring regions significantly contributed to improve regional efficiency.

The analysis of the role of public capital as the main determinants of inefficiency provide evidence that public decision making through the composition of regional public expenditure may greatly influence regional economic performance.

In the face of the continuing political demands to increase the overall level of public investment in Spanish regions with a lower per capita income by transferring fiscal resources from richer regions, our results cast doubt on the ultimate impact of such a simple policy, insofar as there is evidence that an increase in the public to private ratio may negatively influence overall technical efficiency. Instead, a relevant policy 
implication from our analysis is that the less efficient regions may be suffering from a relative deficit of private capital.

The composition of public capital also appears as an important factor influencing inefficiency levels, given that our analysis has shown that the proportion of public capital devoted to transport infrastructures, in the region itself and neighbouring regions, is negatively correlated with technical inefficiency. Thus, the effect of an increase in the public to private capital ratio on inefficiency may be compensated or even reversed if the capital is properly spent on infrastructures that positively affect efficiency.

It is our hope that the findings reported in this paper using the aggregate production function approach encourage other applied researchers to estimate the sources of inefficiency at the firm level in the Spanish regions. 


\section{NOTES}

1. The Krugman specialization index has been calculated as:

$$
I M I_{i t}=\sum_{k=1}^{K} a b s\left(v_{k i t}-w_{k i t}\right)
$$

Where $v_{k i t}$ is the share of sector $k$ in the gross value added of region $i$ and $w_{k i t}$ the share of the same industry in the gross added value of all other regions. We calculated this specialization measure using a dissagregation in 17 sectors.

2. Average estimated elasticities form the translog stochastic frontier are the following: $\Theta_{K}=0.648 ; \Theta_{G}=0.012 ;$ and $\Theta_{H L}=0.306$. Average public capital elasticity is estimated for Spain is very low in comparison with private capital and human capital elasticities. Standard errors have been calculated using the delta method. Only private capital elasticity is significant with $\mathrm{p}<0.05$.

3. Horrace and Schmidt (1996) derived the expressions for (1- $\alpha) 100 \%$ lower confidence bound (LCB) and upper confidence bound (UCB) for TE $\mathrm{E}_{\mathrm{it}}$ : $\mathrm{LCB}_{\mathrm{it}}=\exp \left(-\mu_{\mathrm{it} *}\right.$ $\left.\mathrm{Z}_{\mathrm{L} \sigma *}\right)$, and $\mathrm{UCB}_{\mathrm{it}}=\exp \left(-\mu_{\mathrm{it} t^{*}}-\mathrm{Z}_{\mathrm{U}} \sigma_{*}\right)$, where $\mathrm{Z}_{\mathrm{L}}=\Phi^{-1}\left\{1-(\alpha / 2)\left[1-\Phi\left(-\mu_{\mathrm{it} *} / \sigma_{*}\right)\right]\right\}$ and $\mathrm{Z}_{\mathrm{U}}=\Phi^{-}$ ${ }^{1}\left\{1-(1-\alpha / 2)\left[1-\Phi\left(-\mu_{\mathrm{it} *} / \sigma *\right)\right]\right\}$.

4. Results of differentiating $\quad E\left[\exp \left(-u_{i t} \mid \varepsilon_{i t}\right)\right]=\left[\exp \left(-\mu_{* i t}+0.5 \sigma_{*}{ }^{2}\right)\right] \frac{\Phi\left[\left(\mu_{* i t} / \sigma_{*}\right)-\sigma_{*}\right]}{\Phi\left(\mu_{* i t} / \sigma_{*}\right)}$ with respect to each of the inefficiency effects variables, where $\mu_{* i t}=\sigma_{u}^{2} \bar{\varepsilon}_{i} /\left(\sigma_{u}^{2}+\sigma_{v}^{2} / T\right), \sigma_{*}^{2}=\sigma_{u}^{2} \sigma_{v}^{2} /\left(T \sigma_{u}^{2}+\sigma_{v}^{2}\right)$ and $\Phi(\bullet)$ are the cumulative distribution function of a standard normal random variable, $\bar{\varepsilon}_{i}=(1 / T) \sum_{t} \varepsilon_{i t}$. 


\section{REFERENCES}

Alvarez A, Arias C, Orea L, 2006, "Econometric testing of spatial productivity spillovers from public capital", Hacienda Pública Española, 178, 9-21.

Banco Bilbao Vizcaya, 1964-1979, Renta Nacional de España y su distribución provincial (Fundación BBVA, Bilbao).

Battese G, Coelli T, 1995, “A Model for Technical Inefficiency Effects in a Stochastic Frontier Production Function for Panel Data" Empirical Economics, 20, 325-332.

Boisso D, Grosskopf S, Hayes K, 2000, "Productivity and Efficiency in the US: Effects of Business Cycles and Public Capital" Regional Science and Urban Economics, 30, 663681.

Bosca JE, Escriba J, Murgui M, 2003, "La elasticidad output del capital y su tasa de rentabilidad" Moneda y Crédito, 217, 191-226.

Bosch N, Espasa M, Sorribas P, 2003, "Eficiencia técnica y acciones estructurales en las Comunidades Autónomas" Papeles de Economía Española, 95, 149-159.

Coelli T, 1996, "A Guide to FRONTIER Version 4.1: A Computer Program for Stochastic Frontier Production and Cost Function Estimation" CEPA Working Paper No. 96/07, University of New England, Australia.

Dabán T, Díaz A, Escribà J, Murgui M, 1998, "La base de datos BD.MORES" Working Paper D-98001, Dirección General de Análisis Presupuestario, Ministerio de Economía y Hacienda.

Domazlicky B, Weber W, 1997, "Total Factor Productivity in the Contiguous United States 1977-1986" J ournal of Regional Science, 37, 213-233.

Doménech R, Escribà F, Murgui M, 1999, "Cambios en precios relativos y crecimiento regional", Revista de Economía Aplicada, 7, 5-29.

Duffy J, Papageogiou C, 2000, "A Cross Country Empirical Investigation of the Aggregate Production Function Specification" J ournal of Economic Growth, 5, 87-120.

Färe R, Grosskopf S, Norris M, Zhang Z, 1994, "Productivity Growth, Technical Progress, and Efficiency Change in Industrialized Countries" American Economic Review, 84, 66-83.

Gumbau-Albert M, 1998, "Regional Technical Efficiency: A Stochastic Frontier Approach" Applied Economic Letters, 5, 723-726.

Gumbau-Albert M, 2000, "Efficiency and Technical Progress: Sources of Convergence in the Spanish Regions" Applied Economics, 32, 467-478. 
Hall RE, Jones CI, 1999, "Why do Some Countries Produce so Much More Output per Worker than Others?" The Quarterly Journal of Economics, February, 83-116.

Heshmati A, Kumbhakar S, Hjalmarsson L, 1995, "Efficiency of the Swedish Pork Industry: A Farm Level Study Using Rotating Panel Data 1976-1988" European Journal of Operational Research, 80, 519-533.

Holtz-Eakin D, Schwartz A, 1995, "Spatial Productivity Spillovers from Public Infrastructure: Evidence from State Highways", National Bureau of Economic Research, Working Paper 5004.

Horrace W, Schmidt P, 1996, "Confidence Statements for Efficiency Estimates from Stochastic Frontier Models" J ournal of Productivity Analysis, Vol 7, 257-282.

Hulten C, Schwab R, 1991, "Public Capital Formation and the Growth of Regional Manufacturing Industries" National Tax J ournal, 44, 121-134.

Salinas-Jiménez $M$, "Technological change, efficiency gains and capital accumulation in labour productivity growth and convergence: an application to the Spanish regions", Applied Economics, 35, 1839-1851.

Kodde D, Palm F, 1986, "Wald Criteria for Jointly Testing Equality and Inequality Restrictions" Econometrica, 54 1243-1248.

Kumbhakar S, Wang H, 2005, "Estimation of growth convergence using a stochastic production frontier approach", Economics Letters, 88, 300-305.

Kumbhakar S, Heshmati A, Hjalmarsson L, 1997, "Temporal Patterns of Technical Efficiency: Results from Competing Models" International Journal of Industrial Organization, 15, 597-616.

Mas M, Pérez F, Uriel E, 2006 El stock y los servicios del capital en España y su distribución territorial 1964-2003 (Fundación BBVA, Bilbao).

Maudos J, Pastor JM, Serrano L, 1998, "Convergencia en las regiones españolas; cambio técnico, eficiencia y productividad" Revista Española de Economía, 15, 235264.

Maudos J, Pastor JM, Serrano L, 2000, "Crecimiento de la productividad y su descomposición en progreso técnico y cambio de eficiencia: una aplicación sectorial y regional en España (1964-1993)" Investigaciones Económicas, XXI V, 177-205.

Maudos J, Pastor JM, Serrano L, 2000, "Efficiency and productive specialisation: an application to the Spanish regions" Regional Studies, 34, 829-842.

Maudos J, Pastor JM, Serrano L, 2003, "Human Capital in OECD countries: technical change, efficiency and productivity", International Review of Applied Economics, 17, 419-435. 
Maza A, Villaverde J, 2007, "A state-space approach to the analysis of economic shocks in Spain", J ournal of Policy Modelling, 29, 55-63.

Murrillo-Zamorano L, 2004, "Economic Efficiency and Frontier Techniques" J ournal of Economic Surveys, 18, 34-77;

Oehlert G, 1992, "A Note on the Delta Method" American Statistician, 46, 27-29.

Percoco M, 2004, "Infrastructure and Economic Efficiency in Italian Regions" Networks and Spatial Economics, 4, 361-378.

Pedraja F, Salinas M, Salinas J, 2002, "Efectos del capital público y del capital humano sobre la productividad de las regiones españolas" Papeles de Economía Española, 93, 135-147.

Puig-Junoy J, 2001, "Technical Inefficiency and Public Capital in U.S. States: A Stochastic Frontier Approach" J ournal of Regional Science, 41, 75-96.

Rodríguez-Vález J, Arias-Sampedro C, 2004, "Desbordamiento espacial de la productividad de las infraestructuras: una aplicación con fronteras estocásticas" Estudios de Economía Aplicada, 22, 657-674.

Salinas M, 2003, "Efficiency and Total Factor Productivity Growth in the Spanish Regions: The Role of Human and Public Capital" Growth and Change, 34, 157-174.

Tallman E, Wang P, 1994, "Human Capital and Endogeneous Growth: Evidence from Japan", J ournal of Monetary Economics, 34, 101-124. 
Table 1: Summary of Statistics for Variables in the Stochastic Frontier Model

\begin{tabular}{lrrrr}
\hline \hline Variable & \multicolumn{1}{c}{$\begin{array}{l}\text { Sample } \\
\text { Mean }\end{array}$} & $\begin{array}{l}\text { Standard } \\
\text { Deviation }\end{array}$ & Minimum & Maximum \\
& 10669.96 & 10340.80 & 676.79 & 51423.47 \\
\hline Real Gross Value Added (Y)* & 23491.54 & 23613.88 & 1081.89 & 118196.18 \\
Private Capital (K)* & 4031.28 & 3868.12 & 216.25 & 23830.33 \\
Public Capital (G)* & 5243172 & 4493005 & 554591 & 21017077 \\
Human Capital-adjusted labor supply (HL) & 0.19 & 0.07 & 0.07 & 0.41 \\
Public Capital/ Private Capital (G/K) & 0.69 & 0.10 & 0.51 & 0.91 \\
Ratio Service Industry/ Private Capital (S/K) & & & & 0.11 \\
Ratio Transport Infrastructures/ Public Capital & 0.46 & 0.24 & 0.74 \\
(TI/G) & 34.27 & 33.29 & 0 & 183.96 \\
Spatial Spillovers (SS) & 0.22 & 0.10 & 0.12 & 0.49 \\
Industrial Mix Index (IMI) & & &
\end{tabular}

*millions of 1986 euros

Number of observations: 561 
Table 2: Maximum Likelihood Estimates of the Translog Stochastic Frontier Production Function

\begin{tabular}{|c|c|c|c|}
\hline Variable & Parameter & Coefficient & $\begin{array}{l}\text { Standard } \\
\text { Error }\end{array}$ \\
\hline \multicolumn{4}{|l|}{ Stochastic Frontier Model } \\
\hline Constant & $\beta_{0}$ & 11.59 & $1.007 * *$ \\
\hline Private Capital (K) & $\beta_{\mathrm{K}}$ & 1.38 & $0.3962 * *$ \\
\hline Public Capital (G) & $\beta_{\mathrm{G}}$ & 0.22 & 0.219 \\
\hline Human Capital-adjusted labor supply (HL) & $\beta_{\mathrm{HL}}$ & -2.11 & $0.49 * *$ \\
\hline Year $(t)$ & $\beta_{\mathrm{t}}$ & -0.04 & $0.019 *$ \\
\hline $\mathrm{K}^{2}$ & $\beta_{\mathrm{K}}^{2}$ & -0.32 & $0.075 * *$ \\
\hline $\mathrm{G}^{2}$ & $\beta_{\mathrm{G}}{ }^{2}$ & -0.03 & 0.57 \\
\hline $\mathrm{HL}^{2}$ & $\beta_{\mathrm{HL}}{ }^{2}$ & 0.15 & $0.243 * *$ \\
\hline$t^{2}$ & $\beta_{\mathrm{t}}^{2}$ & 0.001 & 0.001 \\
\hline$K \cdot G$ & $\beta_{\mathrm{KG}}$ & 0.49 & $0.101 * *$ \\
\hline $\mathrm{K} \cdot \mathrm{HL}$ & $\beta_{\mathrm{KHL}}$ & 0.18 & 0.187 \\
\hline$K \cdot \mathrm{t}$ & $\beta_{\mathrm{Kt}}$ & -0.02 & $0.007 * *$ \\
\hline $\mathrm{G} \cdot \mathrm{HL}$ & $\beta_{\mathrm{GHL}}$ & -0.42 & $0.140 * *$ \\
\hline$G \cdot t$ & $\beta_{\mathrm{Gt}}$ & -0.02 & $0.006 * *$ \\
\hline $\mathrm{HL} \cdot \mathrm{T}$ & $\beta_{\mathrm{HLT}}$ & 0.04 & $0.011 * *$ \\
\hline \multicolumn{4}{|l|}{ Inefficiency Effects Model } \\
\hline Constant & $\delta_{0}$ & 0.737 & $0.081 * *$ \\
\hline Year $(t)$ & $\delta \mathrm{t}$ & -0.025 & $0.005^{* *}$ \\
\hline$t^{2}$ & $\delta_{\mathrm{t}}^{2}$ & 0.001 & $0.0002 * *$ \\
\hline Public Capital/ Private Capital (G/K) & $\delta_{\mathrm{G} / \mathrm{K}}$ & 0.394 & $0.054 * *$ \\
\hline $\begin{array}{l}\text { Percent Service Industry/ Private Capital } \\
(\mathrm{S} / \mathrm{K})\end{array}$ & $\delta_{\mathrm{S} / \mathrm{K}}$ & -0.388 & $0.084 * *$ \\
\hline $\begin{array}{l}\text { Percent Transport Infrastructures/ Public } \\
\text { Capital ( } \mathrm{TI} / \mathrm{G})\end{array}$ & $\delta_{\mathrm{TI} / \mathrm{G}}$ & -0.377 & $0.087 * *$ \\
\hline Spatial Spillovers (SS) & $\delta_{\mathrm{ss}}$ & -0.003 & $0.0006 * *$ \\
\hline Industrial Mix Index (IMI ) & $\delta_{\mathrm{IMI}}$ & -0.291 & $0.085^{* *}$ \\
\hline Variance Parameters & $\sigma^{2}$ & 0.0069 & $0.0007 * *$ \\
\hline & $\gamma$ & 0.465 & $0.061 * *$ \\
\hline Log-Likelihood Function & & 688.92 & \\
\hline
\end{tabular}

Notes: The t-ratios are asymptotic t-ratios.

$* * \mathrm{p}<0.01 ; * \mathrm{p}<0.05$ 
Table 3: Generalized LR Test of Hypotheses for Parameters of the Stochastic Frontier Production Function

\begin{tabular}{|c|c|c|c|c|c|}
\hline Test & $\begin{array}{l}\text { Null Hypothesis } \\
\left(\mathrm{H}_{0}\right)\end{array}$ & Log-Likelihood & Value of $\lambda$ & $\begin{array}{l}\text { Critical } \\
\text { Value }\end{array}$ & Decision (at 5\%) \\
\hline 1 & $\mathrm{H}_{0}: \beta_{\mathrm{jk}}=0$ & 607.55 & 162.75 & 8.67 & Rejected $\mathrm{H}_{0}$ \\
\hline 2 & $\mathrm{H}_{0}: \beta_{\mathrm{t}}=\beta_{\mathrm{tt}}=\beta_{\mathrm{jt}}=0$ & 600.70 & 176.45 & 9.39 & Rejected $\mathrm{H}_{0}$ \\
\hline 3 & $\mathrm{H}_{0}: \gamma=\delta_{0}=\ldots . \delta_{7}=0$ & 611.45 & 154.93 & 7.26 & Rejected $\mathrm{H}_{0}$ \\
\hline 4 & $\mathrm{H}_{0}: \delta_{1}=\ldots \ldots \delta_{7}=0$ & 612.02 & 153.79 & 7.96 & Rejected $\mathrm{H}_{0}$ \\
\hline 5 & $\mathrm{H}_{0}: \delta_{0}=0$ & 671.93 & 33.99 & 12.34 & Rejected $\mathrm{H}_{0}$ \\
\hline \multicolumn{6}{|c|}{$\begin{array}{l}\text { Notes: } \lambda \text { likelihood ratio test statistic, } \lambda=-2\left\{\operatorname{Ln}\left[\operatorname{Likelihood}\left(\mathrm{H}_{0}\right)\right]-\operatorname{Ln}\left[\text { Likelihood }\left(\mathrm{H}_{1}\right)\right]\right\} \text { an } \\
\text { approximate chi-square distribution with degrees of freedom equal to the number of } \\
\text { imposed constraints. The asymptotic distribution of the hypothesis test involving a zero } \\
\text { restriction parameter } \gamma \text { has a mixed chi-square distribution; therefore, the critical value } \\
\text { for this test is taken from Kodde and Palm (1986), Table } 1, \text { p. } 1246 .\end{array}$} \\
\hline
\end{tabular}


Table 4: Technical Efficiency Estimates and 95\% Confidence Intervals

\begin{tabular}{|c|c|c|c|}
\hline Regions & TE 1964-1996 & TE 1964 & TE 1996 \\
\hline Andalucía & $\begin{array}{c}0.924 \\
(0.890 ; 0.957)\end{array}$ & $\begin{array}{c}0.767 \\
(0.705 ; 0.829)\end{array}$ & $\begin{array}{c}0.919 \\
(0.854 ; 0.984)\end{array}$ \\
\hline Aragón & $\begin{array}{c}0.926 \\
(0.894 ; 0.959)\end{array}$ & $\begin{array}{c}0.743 \\
(0.682 ; 0.803)\end{array}$ & $\begin{array}{c}0.981 \\
(0.937 ; 1.00)\end{array}$ \\
\hline Asturias & $\begin{array}{c}0.934 \\
(0.897 ; 0.972)\end{array}$ & $\begin{array}{c}0.759 \\
(0.698 ; 0.821)\end{array}$ & $\begin{array}{c}0.949 \\
(0.89 ; 1.00)\end{array}$ \\
\hline Baleares & $\begin{array}{c}0.971 \\
(0.938 ; 0.995)\end{array}$ & $\begin{array}{c}0.929 \\
(0.881 ; 0.977)\end{array}$ & $\begin{array}{c}0.969 \\
(0.917 ; 1.00)\end{array}$ \\
\hline Canarias & $\begin{array}{c}0.927 \\
(0.894 ; 0.961)\end{array}$ & $\begin{array}{c}0.763 \\
(0.701 ; 0.825)\end{array}$ & $\begin{array}{c}0.951 \\
(0.91 ; 0.992)\end{array}$ \\
\hline Cantabria & $\begin{array}{c}0.900 \\
(0.866 ; 0.929)\end{array}$ & $\begin{array}{c}0.743 \\
(0.658 ; 0.896)\end{array}$ & $\begin{array}{c}0.957 \\
(0.893 ; 0.99)\end{array}$ \\
\hline Castilla la Mancha & $\begin{array}{c}0.951 \\
(0.912 ; 0.983)\end{array}$ & $\begin{array}{c}0.827 \\
(0.761 ; 0.894)\end{array}$ & $\begin{array}{c}0.988 \\
(0.929 ; 1.00)\end{array}$ \\
\hline Castilla León & $\begin{array}{c}0.963 \\
(0.93 ; 0.983)\end{array}$ & $\begin{array}{c}0.841 \\
(0.782 ; 0.90)\end{array}$ & $\begin{array}{c}0.993 \\
(0.94 ; 1.00)\end{array}$ \\
\hline Cataluña & $\begin{array}{c}0.949 \\
(0.91 ; 0.983)\end{array}$ & $\begin{array}{c}0.862 \\
(0.815 ; 0.909)\end{array}$ & $\begin{array}{c}0.959 \\
(0.902 ; 1.00)\end{array}$ \\
\hline Extremadura & $\begin{array}{c}0.873 \\
(0.825 ; 0.918)\end{array}$ & $\begin{array}{c}0.764 \\
(0.702 ; 0.826)\end{array}$ & $\begin{array}{c}0.928 \\
(0.872 ; 0.985)\end{array}$ \\
\hline Galicia & $\begin{array}{c}0.911 \\
(0.87 ; 0.951)\end{array}$ & $\begin{array}{c}0.777 \\
(0.714 ; 0.840)\end{array}$ & $\begin{array}{c}0.926 \\
(0.868 ; 0.984)\end{array}$ \\
\hline La Rioja & $\begin{array}{c}0.942 \\
(0.909 ; 0.976)\end{array}$ & $\begin{array}{c}0.821 \\
(0.763 ; 0.878)\end{array}$ & $\begin{array}{c}0.982 \\
(0.938 ; 1.00)\end{array}$ \\
\hline Madrid & $\begin{array}{c}0.970 \\
(0.941 ; 0.997)\end{array}$ & $\begin{array}{c}0.950 \\
(0.918 ; 0.983)\end{array}$ & $\begin{array}{c}0.978 \\
(0.918 ; 1.00)\end{array}$ \\
\hline Murcia & $\begin{array}{c}0.904 \\
(0.865 ; 0.944)\end{array}$ & $\begin{array}{c}0.712 \\
(0.654 ; 0.770)\end{array}$ & $\begin{array}{c}0.927 \\
(0.858 ; 0.996)\end{array}$ \\
\hline Navarra & $\begin{array}{c}0.969 \\
(0.943 ; 0.998)\end{array}$ & $\begin{array}{c}0.815 \\
(0.752 ; 0.877)\end{array}$ & $\begin{array}{c}0.991 \\
(0.943 ; 1.00)\end{array}$ \\
\hline País Vasco & $\begin{array}{c}0.973 \\
(0.955 ; 0.989)\end{array}$ & $\begin{array}{c}0.873 \\
(0.823 ; 0.923)\end{array}$ & $\begin{array}{c}0.983 \\
(0.942 ; 1.00)\end{array}$ \\
\hline Valencia & $\begin{array}{c}0.935 \\
(0.896 ; 0.975)\end{array}$ & $\begin{array}{c}0.801 \\
(0.738 ; 0.865)\end{array}$ & $\begin{array}{c}0.961 \\
(0.900 ; 1.00)\end{array}$ \\
\hline SPAIN & $\begin{array}{c}0.936 \\
(0.902 ; 0.969)\end{array}$ & $\begin{array}{c}0.809 \\
(0.750 ; 0.872)\end{array}$ & $\begin{array}{c}0.964 \\
(0.902 ; 1.00)\end{array}$ \\
\hline
\end{tabular}

TE: a point estimate for technical efficiency $=E\left[u_{i} \mid \varepsilon_{i}=\hat{\varepsilon}_{i}\right]$

Confidence intervals at $95 \%$ in parentheses. 
Table 5: Marginal Effects of the Inefficiency Effects Model Variables

\begin{tabular}{lcc}
\hline \hline Variable & Coefficient & $\begin{array}{l}\text { Standard } \\
\text { Error }\end{array}$ \\
\hline Year (t) & 0.0296 & 0.00166 \\
Ratio Public Capital/ Private Capital (G/K) & -0.4385 & 0.01422 \\
Ratio Service Industry/ Private Capital (S/K) & 1.2807 & 0.02283 \\
Ratio Transport Infrastructures/ Public Capital (TI/G) & 0.083 & 0.01683 \\
Spatial Spillovers (SS) & 0.0056 & 0.00164 \\
Industrial Mix (IMI) & 0.0302 & 0.00166 \\
\hline
\end{tabular}

Notes: All coefficients statistically significant at 95\%. 


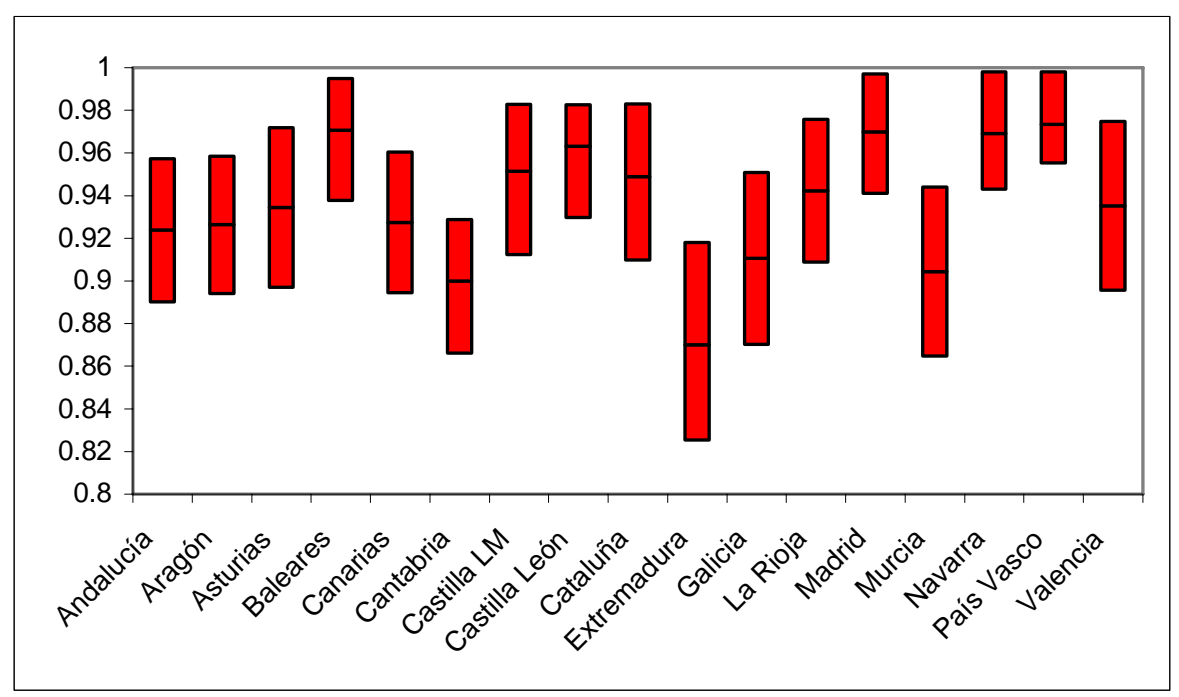

Figure 1: Mean Technical Efficiency Estimates (1964-1996) and 95\% Confidence Intervals 


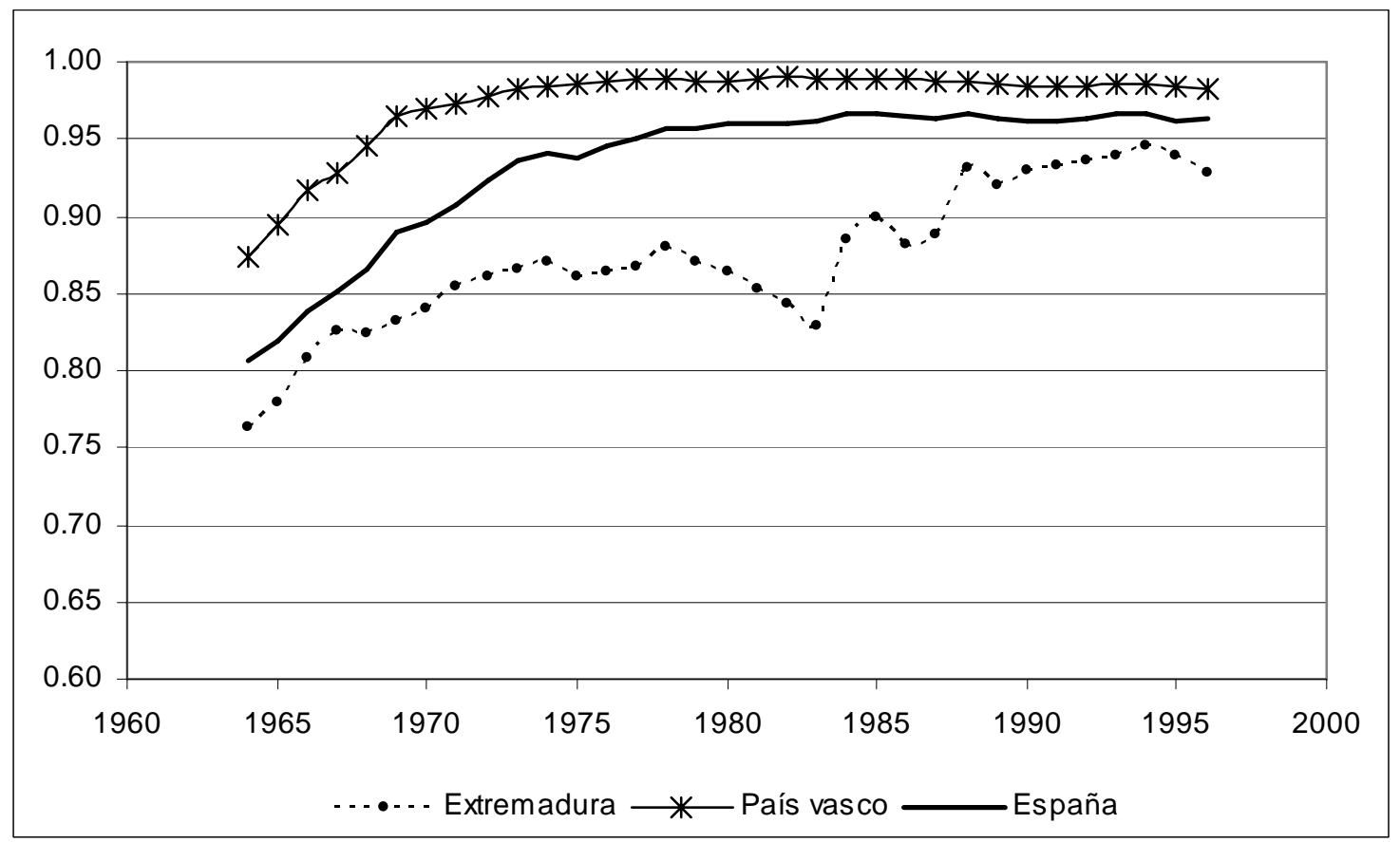

Figure 2. Mean Efficiency Values by Year for some Spanish Regions 